\title{
FINANCIAL AND SOCIAL SUSTAINABILITY PENSION SYSTEMS IN THE FACE OF DEMOGRAPHIC RISKS
}

\author{
Alexander Nepp, ${ }^{1}$ James Okrah²
}

\begin{abstract}
The ongoing distribution of the pension system is on the threshold of losing its sustainability, financially, which has produced a deficit in the budget of the Pension Fund of the Russian Federation and the deflection of pension funds to the distribution system in 2014. This situation was to some extent caused by demographic risks. Funded systems could become the main instrument for mitigating the demographic problem of the distribution pension system. But the problem is, these systems are unprotected to demographic risks as well.

The paper examines the effect of demographic uncertainty on funded pension systems. It describes the process necessary for the financial sustainability of a funded pension system under the force of demographic and macroeconomic factors. It explores the conformity of Russian funded pension systems and that of OECD countries with the status of financial sustainability in the time from 1958 to 2012, making a prognosis for the financial viability prospects.
\end{abstract}

JEL Number: D53, G28; DOI: http://dx.doi.org/10.12955/cbup.v5.947

UDC Number: 336

Keywords: Funded pension systems, unfunded pension systems, financial sustainability, social sustainability, demographic risks, retirement age, duration of pension payments

\section{Introduction}

Demographic risks of a benefits framework are heterogeneous and now and again include not just demographic factors. The examination of statistic dangers partitions all annuity frameworks into two gatherings: subsidized and dispersion (unfunded) benefits frameworks. The main gathering is influenced by such dangers as:

- An expansion in the future, which will influence the span of annuity installments;

- The expanding time of section into the work showcase, impacting the measure of benefits investment funds;

- Variances in the normal retirement age, which will influence both the length of benefits funds and the term of annuity installments.

Dispersion benefits frameworks are affected by statistic dangers to a more noteworthy degree. In this way, notwithstanding those officially recorded above, there are two different sorts of statistic dangers critical for dissemination annuity frameworks:

- An expansion in the quantity of nationals who are beneficiaries of benefits;

- A decrease in the number of the working populace whose commitments and expense installments subsidize benefits.

The impact of demographic risks on pension systems is estimated by considering their impact on such indicators as pension payments and replacement rate. In economics, these indicators tend to be considered as the most important targets of pension systems Vidal-Meliá et al. (2006). The International Labour Organization has made reports containing the recommended minimal and optimal values of the replacement rate.

Analysing the data of the countries, which met the following criteria, carried out the research of distribution pension systems:

- They have a distribution pension system or at least a part of the country's pension system is based on the distribution principle;

- In these countries pension contributions to the distribution pension systems are separated from the overall amount of taxes or mandatory insurance premiums;

- These countries can provide all the necessary statistical data.

For funded pension plans, the research sample included the countries, which meet the following criteria:

\footnotetext{
${ }^{1}$ Ural Federal University, Ekaterinburg, Russia, anepp@inbox.ru

${ }^{2}$ Ural Federal University, Ekaterinburg, Russia, Jokrah6@ gmail.com
} 
- These countries have a funded pension system or at least a part of its pension system is based on this principle;

- Pension contributions to the pension system in these countries are separated from the overall amount of taxes or mandatory insurance premiums;

- These countries can provide all the necessary statistical data.

As a result, the research sample comprised Australia, Austria, Great Britain, Hungary, Germany, Italy, Canada, Luxembourg, Mexico, the Netherlands, Norway, Poland, Slovakia, USA, the Czech Republic, France, Switzerland, Sweden, Japan, Russia, on average in the OECD countries.

Impact of demographic risks on the financial and social sustainability of distribution pension systems

Practical Study of OECD Countries

This study of financial sustainability of distribution pension systems was based on the described systems Nepp (2017). The chosen periods were the one from 1990 to 2012 and the forecast period from 2012 to 2050. The study involved nineteen OECD countries meeting the following criteria: a) they should have a distribution pension system or at least a part of their pension system should be based on this principle; b) pension contributions into their distribution pension systems should be separated from the overall amount of taxes or mandatory insurance contributions; c) these countries should be able to provide all the necessary statistical data. Therefore, our research sample comprised the following countries: Australia, Austria, Great Britain, Hungary, Germany, Italy, Canada, Luxembourg, Mexico, the Netherlands, Norway, Poland, Slovakia, the USA, the Czech Republic, France, Switzerland, Sweden, Japan, and Russia.

This research focused on the dynamics of pension payments and the dynamics of the support ratio. Therefore, the rates of pension payments change were determined as the ratio of pension payments in 2012 and 1990:

Temp..PS $=\frac{P S_{2012}}{P S_{1990}}$

The rates of support ratio were determined the following way:

Temp..Kp $=\frac{K p_{2012}}{K p_{1990}}$

To maintain financial sustainability of distribution pension systems however, it is crucial to consider not only demographic factors but also the dynamics of pension contributions, which depend on the average salary and the pension contribution rates.

To achieve this, we compared the rates of change of pension payments (3) with those of the support ratio (15), which is illustrated by the formula:

$$
\Delta \text { TempPS / Kp }=\frac{\mid \text { TempPS }-1 \mid}{\mid \text { Temp.Kp }-1 \mid}
$$

Where:

$\triangle T e m p P S / K p$ is the excess of rates of pension contributions TempPS in comparison to the rates of the support ratio $\mathrm{Kp}$.

The analysis of different pension systems done by applying the expression (5) led us to conclusions about the chosen countries' financial sustainability or the lack of it: 


$$
\left\{\begin{array}{l}
\triangle T e m p P S / K p=\frac{\mid \text { TempPS }-1 \mid}{\mid \text { Temp..Kp-1|}} \\
\text { Lack of financial sustainability if } \triangle T e m p P S / K p \geq 1 \\
\text { Financial sustainability if } \triangle T e m p P S / K p \leq 1
\end{array}\right.
$$

The ability to maintain financial sustainability was checked by applying the system (6). If the rates of pension contributions growth exceeded those of the support ratio reduction, that is, the losses of funds as a result of a decrease in the number of employed population were compensated by pension contributions ( $\triangle T e m p P S / K p \geq 1$ ), then the distribution pension system met the requirement of being able to maintain its financial sustainability. If $\triangle T e m p P S / K p \leq 1$, then the country's distribution pension system became less financially stable, which meant that the growth of pension contributions did not make up for the losses caused by demographic risks or the reduction in the number of working population. The area of financial sustainability of distribution pension systems was, in its turn, divided into three subareas:

$$
\left\{\begin{array}{l}
\Delta T e m p P S / K p \in[1 ; 3] \ldots . . \text { sufficient financial sustainbility } \\
\triangle T e m p P S / K p \in[3 ; 6] \ldots . . . \text { good financial sustainbility } \\
\Delta T e m p P S / K p \geq 6 \ldots . . . . . \text { excellent ...finanzial...sustainbility }
\end{array}\right.
$$

The results of financial sustainability survey of the countries in question, calculated according to the formula Nepp (2017), are illustrated in Figure 1.

Figure 1: Demographic risks of distribution pension systems. Maintenance of financial sustainability from 1990 to 2012 .

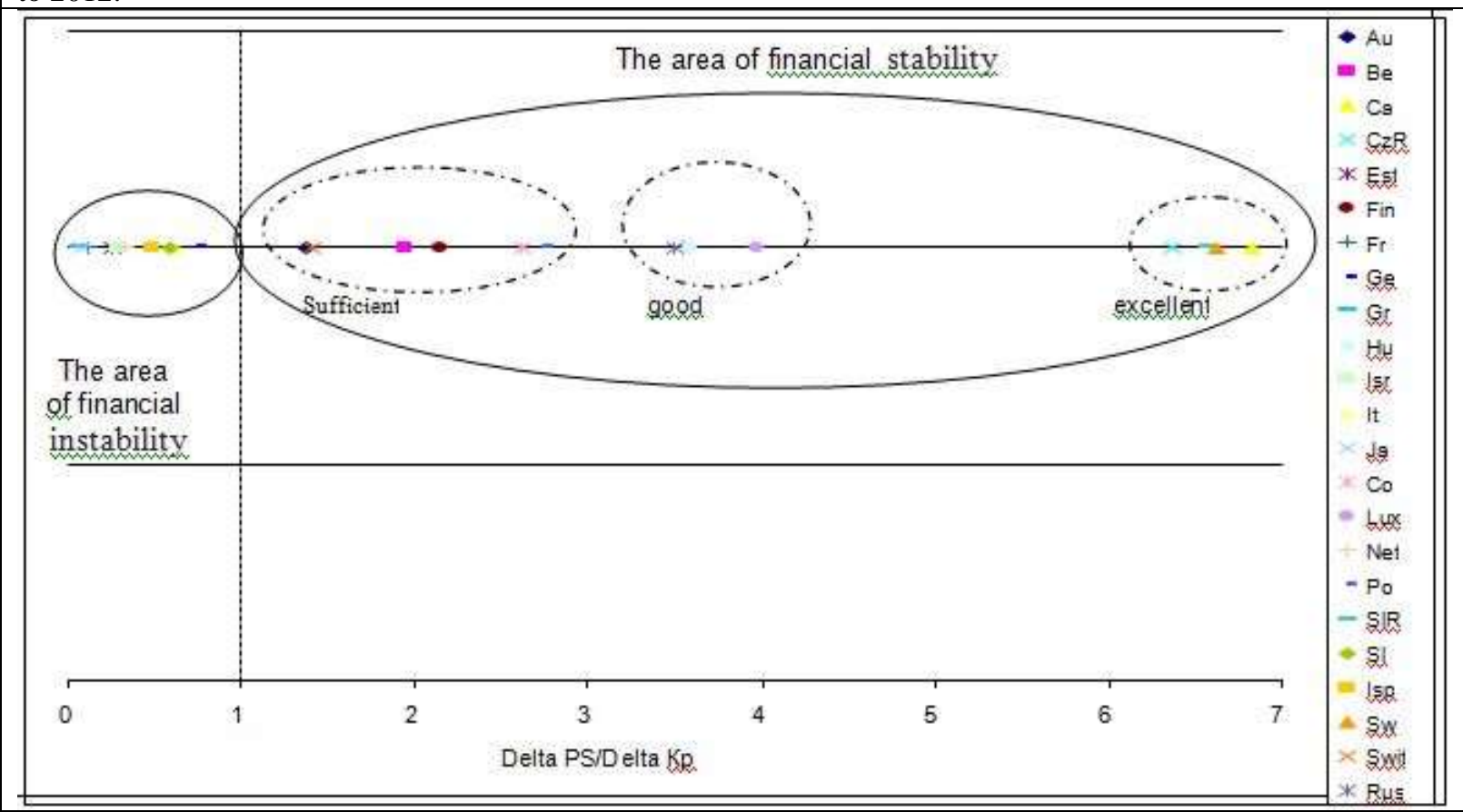

Figure 1: "calculated by the authors on the basis of statistical data OECD (Pensions at a glance 2011: retirement -incomesystemsinOECDandG20 countries .OECD. 2011. P. 124") 
As it can be seen from Figure 1, the area characterized by the lack of financial sustainability in the period between 1990 and 2012 includes the distribution pension systems of such countries as Germany, Italy, Slovenia, Spain, the Netherlands, Israel, Estonia, France, Japan, and Greece. The rise in pension contributions compensates for the losses caused by demographic risks and the reduction in the number of working population. Importantly, in such countries as Canada, Sweden, Slovakia, the Czech Republic, Luxembourg, Hungary, Russia, Poland, Korea, Finland, Belgium, Switzerland, and Austria, it is the working population, which provides financial sustainability. As Figure 1 shows, there is a significant gap between the countries characterized by the lack of financial sustainability: these countries were divided into three groups. In accordance, the first group includes countries with excellent financial sustainability in distribution pension systems: the indicator exceeds 6 . This group comprises Canada, Sweden, Slovakia, and the Czech Republic. The second group consists of countries with good financial sustainability: Luxembourg, Hungary, and Russia. The group with sufficient financial sustainability comprises Poland, Korea, Finland, Belgium, Switzerland, and Austria. (See Table 1).

As it has been mentioned above, the countries, which have managed to preserve their financial sustainability, achieved this through the increase in pension contributions, that is, the tax burden and/or an increase in wages.

Table 1: Financial sustainability of distribution pension systems achieved by handling demographic risks by means of increasing the level of wages and pension contribution rates from 1990 to 2012.

\begin{tabular}{|c|c|c|c|c|}
\hline \multirow{2}{*}{$\begin{array}{l}\text { Pension } \\
\text { contribution } \\
\text { rates }\end{array}$} & \multirow{2}{*}{$\begin{array}{l}\text { Distribution pension } \\
\text { systems of the countries } \\
\text { which do not meet the } \\
\text { requirement for financial } \\
\text { sustainability (17) }\end{array}$} & \multicolumn{3}{|c|}{$\begin{array}{l}\text { Distribution pension systems of the countries which meet the } \\
\text { requirement for financial sustainability (17) }\end{array}$} \\
\hline & & $\begin{array}{l}\text { Sufficient financial } \\
\text { sustainability }\end{array}$ & $\begin{array}{l}\text { Good financial } \\
\text { sustainability }\end{array}$ & $\begin{array}{l}\text { Excellent financial } \\
\text { sustainability }\end{array}$ \\
\hline $\begin{array}{l}\text { Changed in } \\
\text { accordance } \\
\text { with the } \\
\text { actual } \\
\text { situation }\end{array}$ & $\begin{array}{l}\text { Germany } \\
\text { Italy } \\
\text { Spain } \\
\text { Slovenia } \\
\text { Netherlands } \\
\text { Israel } \\
\text { Estonia } \\
\text { France } \\
\text { Japan } \\
\text { Greece }\end{array}$ & $\begin{array}{l}\text { Poland } \\
\text { Korea } \\
\text { Finland } \\
\text { Belgium } \\
\text { Switzerland } \\
\text { Austria }\end{array}$ & $\begin{array}{l}\text { Luxembourg } \\
\text { Hungary } \\
\text { Russia }\end{array}$ & $\begin{array}{l}\text { Canada } \\
\text { Sweden } \\
\text { Slovakia } \\
\text { Czech Republic }\end{array}$ \\
\hline $\begin{array}{l}\text { Were fixed } \\
\text { at the level } \\
\text { of } 1990\end{array}$ & $\begin{array}{l}\text { Spain } \\
\text { Germany } \\
\text { Slovenia } \\
\text { Netherlands } \\
\text { Greece } \\
\text { Japan } \\
\text { Italy }\end{array}$ & $\begin{array}{l}\text { Poland } \\
\text { Hungary } \\
\text { Estonia } \\
\text { Belgium } \\
\text { Israel } \\
\text { Canada } \\
\text { Switzerland } \\
\text { France } \\
\text { Austria } \\
\text { Russia } \\
\text { Finland } \\
\text { Korea }\end{array}$ & Luxembourg & $\begin{array}{l}\text { Sweden } \\
\text { Czech Republic }\end{array}$ \\
\hline
\end{tabular}


Such measure as maintaining pension systems' financial sustainability by increasing the rates of pension contributions should not be underestimated. For instance, if pension contribution rates remained at the level of 1990, it would greatly affect financial sustainability (see Table 1). According to this table, with the tax burden staying at the level of 1990, such countries as Spain, Germany, Slovenia, the Netherlands, Greece, Japan, and Italy are bound to experience problems with financial sustainability. Unlike the actual situation (see Table on page 81 and its discussion), this group no longer includes such countries as Spain, Israel, Estonia, and France, which have become financially unstable due to the fall in pension contributions. Nonetheless, excellent and good financial sustainability with the taxation burden remaining at the level of 1990 is preserved only in three countries: Sweden, the Czech Republic, and Luxembourg. Thus, Canada, Slovakia, Hungary, and Russia have maintained their financial sustainability at high or quite high levels by increasing the rates of pension contributions. Otherwise, they would be in the group of countries with sufficient financial sustainability.

Analysing the brunt of demographic risks of the main indicators of pension systems, we assumed that it is essential to maintain financial sustainability of a pension system provided that there is no indexation of wages and growth of pension contribution rates. For Russia, the indicator will make 1.14 if pension contribution rates remain at the level of 1990, which brings to light the Russian pension system's weak financial sustainability and a small likelihood of its being maintained with the help of an increase in wages. The problem seems even more serious if we take into consideration the low replacement rate in the Russian pension system ( 0.34 as compared to 0.6 , recommended by the International Labour Organization) Gurvich (2011). The deterioration of the Russian pension system's financial sustainability became even more evident when the budgetary allocations to the Pension Fund increased from 248 billion rbs in 2005 to 1,940 billion in 2013, Dmitrieva (2013).

Table 2: Necessary changes of pension contributions rates to provide financial sustainability of distribution pension systems from 2012 to 2050 .

\begin{tabular}{|l|l|l|l|}
\hline & Pension & $\begin{array}{l}\text { Growth of pension } \\
\text { contribution rates to } \\
\text { provide financial } \\
\text { sustainability of the } \\
\text { distribution pension } \\
\text { systems in 2050. }\end{array}$ & $\begin{array}{l}\text { Pension contribution } \\
\text { rates in 2050 which } \\
\text { would provide } \\
\text { financial sustainability } \\
\text { of the distribution } \\
\text { pension systems in } \\
\text { 205050 }\end{array}$ \\
\hline 1 & 2 & 3 & 4 \\
\hline Luxembourg & 22.8 & 1.399265431 & 31.90325182 \\
\hline Czech & & & 2612 \\
Republic & 16.4 & 1.639420659 & 26.82092198 \\
\hline Sweden & 28.0 & 1.818625351 & 50.92150983 \\
\hline Hungary & 22.8 & 1.490738119 & 33.98882911 \\
\hline Belgium & 16.7 & 1.247939559 & 20.77819365 \\
\hline Austria & 19.6 & 1.579136274 & 30.95107097 \\
\hline Spain & 20.0 & 2.386874009 & 47.73748018 \\
\hline Finland & 34.0 & 1.522481987 & 51.76438756 \\
\hline Greece & 33.0 & 1.433550429 & 47.30716416 \\
\hline Poland & 16.0 & 1.9755124 & 31.6081984 \\
\hline Italy & 17.9 & 1.873396171 & 33.53379146 \\
\hline Germany & 19.5 & 1.317743657 & 25.72235619 \\
\hline Netherlands & 28.3 & 2.281373752 & 64.56287717 \\
\hline France & 18.4 & 0.857253339 & 15.75631637 \\
\hline & & & \\
\hline
\end{tabular}

Source: Nepp, A.N. The role of demographic risks for the unfunded pension systems (2013) World Applied Sciences Journal, 27 (13 A), pp. 234-240 


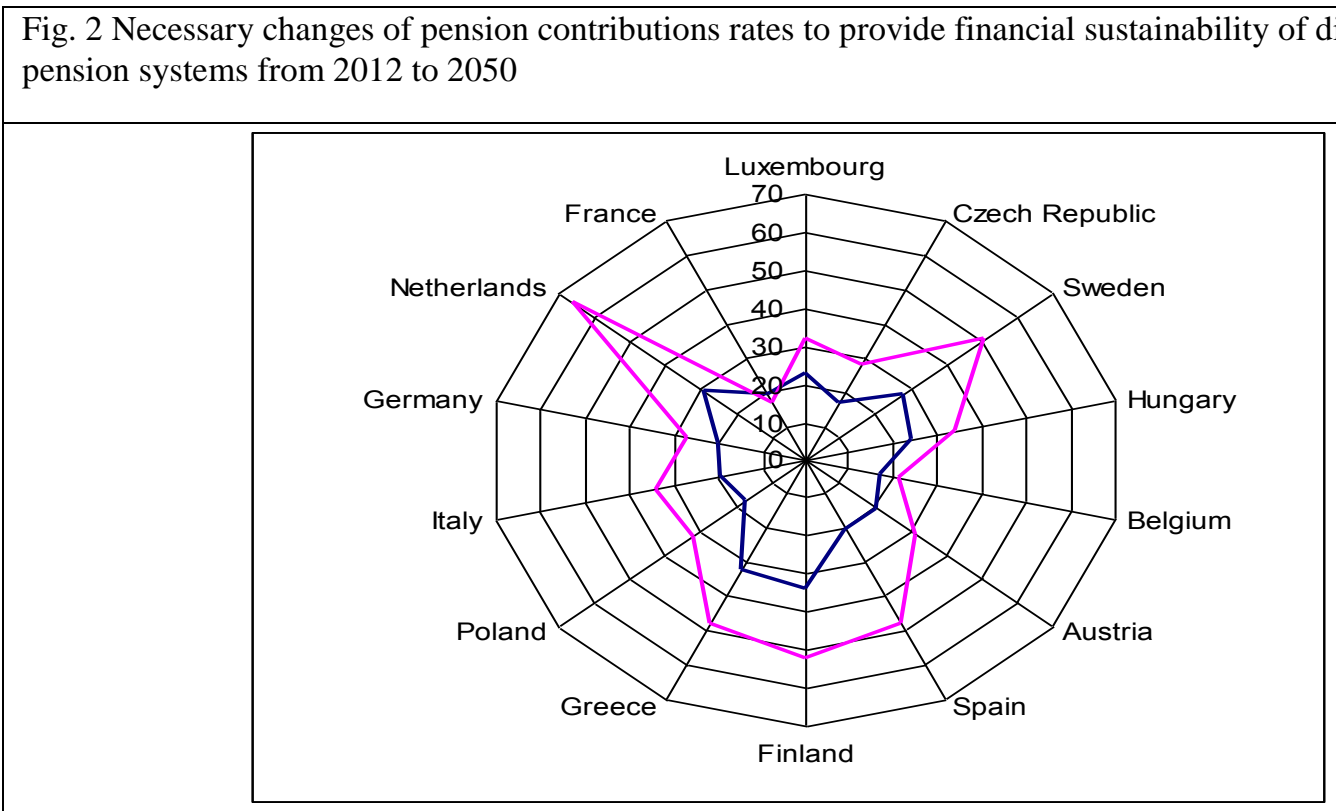

Figure 2: Graphically represents the results of Table 2

Note: the blue line corresponds to the rates of pension contributions in 2012; the red one, to those in 2050. As our analysis has revealed, when faced with demographic risks, the distribution pension systems demonstrate neither financial nor social sustainability (maintenance of the replacement rate). It is obviously impossible to raise the replacement rate only with the help of wages increase and without an increase in tax burden on enterprises

\section{Conclusion}

1.When wages stagnate and pension contribution rates are non-estimated, financial sustainability of distribution pension systems will be determined predominantly by demographic factors, such as the number of retired people and the number of employed population or by the support ratio, which characterized the ratio of the number of working population to the number of pensioners.

2. The impact of demographic risks on distribution pension systems makes it impossible to maintain social sustainability of pension systems, that is, to maintain the replacement rate, provided that the distribution principles in most of the described countries remain the same.

\section{Acknowledgement}

This research is supported by the Russian Science Foundation RSF Grant No 15-18-10014 'Projection of optimal socio-economic systems in turbulent external and internal environments'.

\section{References}

Debón, A., Montes, F., Puig, F. (2008) Modelling and Forecasting Mortality in Spain. European Journal of Operational Research. Volume 189, Issue 3, 16 September 2008, P. 624-637

Dmitrieva O. (2013) Economic Turnovers and Financial 'Vacuum Cleaners'. Voprosy Ekonomiki, № 7, July 2013, P. 49-62 Gurvich E.T., Sonina Y.V. (2012) Microanalysis of the Russian Pension System. Voprosy Ekonomiki. 2012. № 2. P. 27-51 Gurvich E.T. (2011) Principles of the New Pension Reform. Voprosy Ekonomiki. 2011. № 4. 4-32 p.

Mesle F., Vallin J. (2006). The Health Transition: Trends and Prospects. Demography: Analysis and Synthesis. A Treatise in Demography / G. Caselli, J. Vallin, G. Wunsch (eds.). N.Y.: Elsevier. P. 247 - 602

Nepp A. (2013) The Role of Demographic Risks for Unfunded Pension Systems. World Applied Sciences Journal. Issue 27. pages 234-240

Kenichi Hirose (2011) Pension Reform in Central and Eastern Europe in Times of Crisis, Austerity and Beyond. Edited by Kenichi Hirose; International Labour Organization, Decent Work Technical Support Team for Central and Eastern Europe. Budapest: ILO, 2011. 325 p

Vidal-Meliá, C., Domínguez-Fabián, I., Devesa-Carpio, J.E. (2006) Subjective Economic Risk to Beneficiaries in Notional Defined Contribution Accounts. Journal of Risk and Insurance. Volume 73, Issue 3, September 2006, Pages 489-515 